\title{
PROSES PERENCANAAN ANGGARAN BERBASIS KINERJA PADA POLITEKNIK PEMBANGUNAN PERTANIAN MALANG
}

\author{
Kuncoro Adhi ${ }^{1}$, Abdul Hakim ${ }^{2}$, Mochmamad Makmur ${ }^{3}$ \\ Fakultas Ilmu Administrasi, Universitas Brawijaya \\ Email: kuncoroadhie84@gmail.com¹, abdulhakim@ub.ac.id², mmakmur fia@ub.ac.id
}

\begin{abstract}
This study aims to describe and analyze the performance-based budget planning process at Malang Agricultural Development Polytechnic. This study uses a qualitative descriptive approach with data collection techniques through observation, interviews, and documentation. The results of this study indicate that the planning process carried out by Malang Polbangtan refers to the stages outlined in the National Development Planning System which consists of the preparation of plans, determination of plans, control of the implementation of the plan, and evaluation of the implementation of the plan. At the planning stage, the input used in the preparation is still a rough estimate based on trends and has not been supported by valid data. As a result, changes to what was planned in the implementation of the plan were often carried out. Control and evaluation has not been supported by the existence of internal policies that in writing provide guidance in determining the performance indicators of each program or activity that has been planned, so that in determining the performance achievements of the program and activities activities are hampered, because performance indicators are not performance oriented.
\end{abstract}

Keyword: Planning process, performance-based budgeting, National Development Planning System.

\begin{abstract}
ABSTRAK
Penelitian ini bertujuan untuk mendeskripsikan dan menganalisis proses perencanaan anggaran berbasis kinerja pada Politeknik Pembangunan Pertanian Malang. Penelitian ini menggunakan pendekatan deskriptif kualitatif dengan teknik pengumpulan data melalui observasi, wawancara, dan dokumentasi. Hasil dari penelitian ini menunjukkan bahwa proses perencanaan yang dilaksanakan oleh Polbangtan Malang mengacu pada tahapan yang digariskan dalam Sistem Perencanaan Pembangunan Nasional yang terdiri dari penyusunan rencana, penetapan rencana, pengendalian pelaksanaan rencana, dan evaluasi pelaksanaan rencana. Pada tahap penyusunan rencana, input yang digunakan dalam penyusunan masih bersifat perkiraan kasar berdasarkan tren dan belum didukung oleh data yang valid. Akibatnya, dalam pelaksanaan rencana sering dilakukan perubahan atas apa yang direncanakan sebelumnya. Pengendalian dan evaluasi belum didukung oleh adanya kebijakan internal yang secara tertulis memberikan panduan dalam menentukan indikator kinerja dari setiap program atau kegiatan yang telah direncanakan, sehingga dalam penentuan capaian kinerja dari pelaksanaan program dan kegiatan tersebut menjadi terhambat, dikarenakan indikator kinerja yang tidak berorientasi terhadap kinerja.
\end{abstract}

Keyword: Proses perencanaan, anggaran berbasis kinerja, Sistem Perencanaan Pembangunan Nasional. 


\section{A. PENDAHULUAN}

Perencanaan anggaran sektor publik di Indonesia terus mengalami perubahan dan perkembangan beriringan dengan usaha yang dilakukan oleh pemerintah dalam perbaikan tata kelola pemerintahan serta semangat menjunjung tinggi akuntabilitas publik dalam pengelolaan keuangan negara. Perbaikan dalam pengelolaan keuangan negara terus dilakukan pasca diterbitkannya Undang-Undang Keuangan Negara dan Undang-Undang Perbendaharaan Negara pada tahun 2003 silam. Pada aspek perencanaan,Undang-Undang Sistem Perencanaan Pembangunan Nasional menjadi panduan bagi pemerintah pusat dan daerah dalam dalam pelaksanaan proses perencanaan di Indonesia. Mardiasmo (2002) menyampaikan bahwa dalam perencanaan dan penganggaran pada sektor publik, dikenal dua buah pendekatan yang diterapkan oleh beragam negara, yaitu tradisional dan pendekatan baru dalam new public management yang berfokus utama pada kinerja atau lebih dikenal dengan penganggaran berbasis kinerja. Anggaran tradisional meskipun sudah banyak ditinggalkan oleh negara-negara maju, tapi masih saja diterapkan di negara-negara dengan status berkembang. Anggaran tradisional dikenali dengan ciri utama yaitu disusun atas pendekatan incrementalism serta tatanan dan susunannya yang bersifat line item(Mardiasmo:2002). Struktur anggaran tradisional sebagaimana diungkapkan Mardiasmo (2002) tidak mampu mengungkapkan besaran dana yang dikeluarkan untuk setiap kegiatan serta belum bisa mengungkap secara gamblang mengenai rencana serta kegiatan yang akan dilakukan.

Penerapan pendekatan kinerja dalam penganggaran diharapkan mampu mengatasi kelemahan dalam penganggaran tradisional yang terkadang belum mempunyai tolak ukur dalam menilai dan mengukur kinerja organisasi sektor publik dalam mencapai tujuan dan sasaran yang telah ditetapkan. Pendekatan ini selain menekankan pada konsep value of money dan pengawasan atas kinerja output, memberikan penekanan dalam menentukan dan membuat prioritas tujuan serta penggunaan metode yang rapi serta rasional dalam mengambil sebuah keputusan. Anggaran berbasis kinerja merupakan sebuah sistem mencakup perencanaan, penganggaran, serta evaluasi dengan tetap berusaha mengaitkan antara anggaran yang dikeluarkan dengan hasil yang dikehendaki. Anggaran kinerja berorientasi utama pada tujuan dan sasaran kinerja, sehingga anggaran yang tersedia digunakan sebagai sarana untuk mencapai tujuan serta mendasarkan penilaian kinerja dengan mengedepankan prinsip value for money dan efektifitas dalam penggunaan anggaran.

Implementasi anggaran berbasis kinerja di Indonesia dimulai sejak diterbitkannya Undang-Undang Keuangan Negara pada 2003 silam. Tahapan yang harus dilakukan dalam pengimplementasian penganggaran berbasis kinerja bermula dari dilakukannya perencanaan atas kinerja yang akan dicapai, dimulai dari tataran jabatan tertinggi sampai dengan terendah yang ada pada suatu kementerian atau lembaga. Perencanaan kinerja memuat tentang komitemen kinerja yang hendak dihasilkan serta dipertajam dalam program serta kegiatan yang akan dilaksanakan dalam satuan waktu tertentu. Selain pengajuan rencana kinerja, kementerian atau lembaga juga diharuskan untuk membuat kerangka kebutuhan pendanaan yang diperlukan dalam melaksnaakan program dan kegiatan yang ada pada organisasi tersebut sesuai dengan alokasi serta target yang telah ditetapkan sebelumnya dan dituangkan dalam dokumen Rencana Kerja Anggaran Kementerian/Lembaga (RKAK/L) yang nantinya dibahas oleh DPR RI sebagai usulan resmi pemerintah atau RAPBN.

Penganggaran berbasis kinerja meskipun sudah diperkenalkan cukup lama di Indonesia, namun belum sepenuhnya dilaksanakan pada proses perencanaan dan penganggaran yang dilaksanakan setiap tahun pada instansi pemerintah. Mulihartanti (2013) mengungkapkan bahwa dalam prakteknya, penyusunan anggaran dengan pendekatan tradisonal seringkali masih dilakukan oleh organisasi sektor publik dalam perencanaan anggaran. Penelitian tersebut juga mengungkapkan terkait beberapa hal yang menjadi penghambat serta kendala dalam menyusun anggaran berbasis kinerja. yaitu kurangnya pemahaman, pengetahuan, dan motivasi pegawai untuk menerapkan secara optimal serta tidak adanya sistem pengukuran kinerja terhadap outcome yang dihasilkan. Bentuk lain dari belum diterapkannya penganggaran berbasis kinerja dalam proses atau mekanisme penyusunan anggaran tampak pada belum ditetapkannya indikator kinerja untuk mengukur hasil dari pengeluaran 
anggaran yang dilakukan (Andriani dan Hatta, 2012). Affandi (2016) mengungkapkan bahwa kendala yang muncul dalam pada saat dilakukannya proses penganggaran berbasis kinerja Dinas Tenaga kerja Tanjung Balai terletak pada masih rendahnya kualitas SDM, kurangnya koordinasi internal, belum adanya indikator kinerja yang jelas serta keterbatasan anggaran.

Anggaran berbasis kinerja menurut Bastian (2006)sebagaimana diungkapkan oleh Mulihartanti (2013), memuat komponenkomponen terkait visi, misi dan rencana strategis yang terdapat pada setiap organisasi sektor publik. Visi, misi dan rencana strategis merupakan hal pokok yang tidak bisa dilepaskan dari anggaran berbasis kinerja mengingat penyusunan anggaran berbasis kinerja berpijak dari ditetapkannya sasaran strategis dan indikator kinerja yang merupakan jabaran daripada visi misi organisasi. Penyusunan anggaran berbasis kinerja memerlukan sebuah penetapan sasaran strategis dan indicator kinerja sebelumnya, tujuannya adalah agar kinerja anggaran dapat diwujudkan berdasar atas target dan ukuran yang telah ditetapklan sebelumnya. Tujuan dari dilakukannya pengukuran kinerja pada suatu organisasi sektor publik adalah agar berhasil atau tidaknya manajemen dalam mencapai target dan sasaran dapat diketahui serta menjadi dasar dalam memberikan penghargaan atas capaian atau bahkan hukuman atas kegagalan dalam mencapai suatu target yang telah ditetapkan. Perencanaan yang telah disusun, seringkali dapat digagalkan oleh tidak efektifnya anggaran serta oleh anggaran yang tidak berorientasi kepada kinerja. Menurut Bastian (2006), pengukuran kinerja yang dilakukan secara berkelanjutan dapat menjadi umpan balik dalam melakukan perbaikan untuk mewujudkan keberhasilan di masa yang akan datang.

Alokasi pagu anggaran Polbangtan Malang pada tahun anggaran 2016-2019 terus mengalami kenaikan, berbanding lurus dengan target keluaran yang harus dihasilkan oleh Polbangtan serta adanya penambahan kegiatankegiatan baru yang merupakan produk kebijakan unit eselon I Badan Penyuluhan dan Pengembangan SDM Pertanian. Data lengkap terkait pagu anggaran Polbangtan Malang berdasarkan jenis belanja periode tahun 20162019 tersaji dalam grafik berikut:

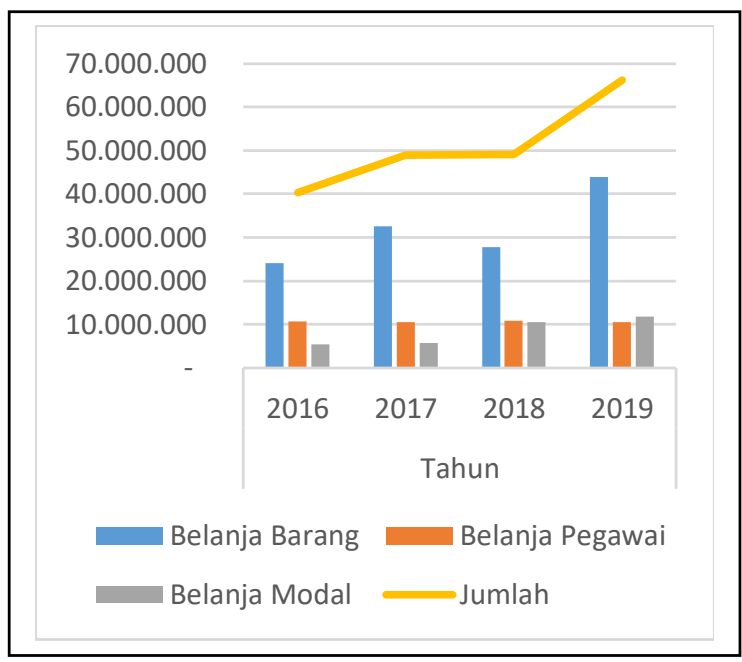

Gambar 1. Pagu Anggaran Polbangtan Malang Tahun 2016-2019

Sumber: DIPA Polbangtan Malang 2016-2019

Meskipun terus mengalami kenaikan dari sisi pendanaan, perubahan komposisi kegiatan dan anggaran pada tahun anggaran berjalan melalui mekanisme revisi DIPA masih acapkali dilakukan. Sebagai institusi pendidikan tinggi, Polbangtan Malang selain mempunyai kewajiban menjalankan Tri Dharma Pendidikan Tinggi, juga harus menjalankan program dan kegiatan tambahan sebagai bagian dari Unit Pelaksana Teknis Kementerian Pertanian dalam mewujudkan kedaulatan pangan dan kesejahteraan petani di Indonesia. Kegiatan tambahan yang berlabel Upaya Khusus Peningkatan Produksi Padi, Jagung dan Kedelai Mewujudkan Swasembada Pangan tersebut, berdasarkan pengamatan peneliti terlihat kurang matang dalam perencanaan dan pelaksanaannya. Dampaknya, kinerja organisasi secara keseluruhan menjadi terganggu meskipun tetap bisa berjalan.

Berdasarkan pengamatan peneliti, proses perencanaan dan penganggaran pada Politeknik Pembangunan Pertanian masih belum dilaksanakan dengan baik. Waktu dan jadwal pelaksanaan kegiatan belum disusun secara tepat dan cermat serta belum bisa langsung dieksekusi pada tahun anggaran berjalan karena terbatasnya data serta informasi yang digunakan sebagai dasar dalam penysuunan rencana, sehingga harus dilakukan revisi anggaran terlebih dahulu untuk bisa melaksanakannya.Dalam pelaksanaannya, adanya tuntutan kontribusi dalam mendukung program prioritas Kementerian Pertanian sebagai institusi induk seringkali 
mengorbankan standar minimal pembiayaan kegiatan yang dilaksanakan pada Polbangtan. Penetapan besaran belanja pada Polbangtan dilakukan sebatas memenuhi usulan pelaksana kegiatan dan belum didasarkan pada target kinerja keluaran (output) atau hasil (outcome) yang akan dicapai sebagaimana yang dicirikan dalam prinsip penganggaran berbasis kinerja. Data yang peneliti kumpulkan dilapangan memperlihatkan adanya intensitas yang dilakukan oleh Polbangtan Malang dalam melakukan revisi kegiatan dan anggaran pada periode 2016-2018 sebagaimana tersaji dalam tabel berikut:

Tabel 1. Revisi DIPA Polbangtan Malang 20162018

\begin{tabular}{|c|c|c|}
\hline No & Tahun & $\begin{array}{c}\text { Jumlah } \\
\text { Revisi }\end{array}$ \\
\hline 1 & 2016 & 7 \\
\hline 2 & 2017 & 11 \\
\hline 3 & 2018 & 11 \\
\hline
\end{tabular}

Hal pertama yang harus dipikirkan ketika hendak menggunakan pendekatan kinerja dalam penyusunan anggaran adalah fokus utama pada target yang akan dicapai. Ketika fokus tertuju pada output yang akan dicapai, maka segala sesuatu yang berkaitan dengan tujuan kegiatan hendaknya sudah terpenuhi pada setiap tahapan dilakukannya penyusunan anggaran. Sistem anggaran berbasis kinerja, selain berfokus utama kepada efisiensi dalam penggunaan anggaran, juga berfokus pada evaluasi atas capaian yang telah dihasilkan. Tolak ukur utama yang menjadi patokan keberhasilan dilaksanakannya sistem anggaran berbais kinerja terletak pada performance atau prestasi yang dihasilkan melalui efisiensi dalam penggunaan dana.Penelitian ini mencoba mengungkapkan dan menganalisis proses perencanaan yang dilakukan oleh Politeknik Pembangunan Pertanian Malang serta kaitannya dengan penggunaan komponen anggaran berbasis kinerja.

\section{B. KAJIAN PUSTAKA}

Perencanaan dinyatakan oleh Tjokroamidjojo (1995) sebagai suatu rangkaian tindakan untuk menyiapkan secara sistematis beberapa kegiatan yang akan dilaksanakan dalam mencapai suatu tujuan tertentu. Saul M. Ketz, dalam bukunya A System Approach to Development Administration, dalam Tjokroamidjojo (1995), mengungkapkan bahwa perencanaan merupakan suatu hal yang sangat penting, yaitu :

a. Perencanaan sebagai acuan dalam melaksanakan kegiatan dalam mencapai tujuan pembangunan

b. Perencanaan sebagai sebuah prediksi terkait hal-hal yang akan dilalui oleh sebuah rencana. Prediksi tersebut dapat berupa hambatan, resiko serta pengembangan dari rencana yang sudah ditetapkan sebelumnya

c. Perencanaan memungkinkan untuk memilih dan memutuskan metode terbaik atau bahkan gabungan beberapa metode

d. Perencanaan dapat memandu dalam menentukan skala prioritas, menempatkan sesuai urgensi suatu tujuan serta sasaran serta aktivitasnya

e. Perencanaan sebagai panduan serta acuan dalam membuat pengawasan atas suatu kegiatan

Sistem Perencanaan pembangunan Nasional yang dicanangkan dalam UU 25 tahun 2004 merupakan acuan dalam pelaksanaan perencanaan pembangunan di Indonesia. Sistem perencanaan pembangunan nasional, menurut Undang-Undang tersebut didefinisakan sebagai sebuah kesatuan tata cara dalam perencanaan dalam menghasilkan rencana pembangunan yang akan dilaksanakan dalam jangka waktu tertentu yang akan dijalankan oleh pemerintah baik yang berada di tingkat pusat serta daerah.

Tujuan dilaksanakannya Sistem Perencanaan pembangunan Nasional sebagaimana tercantum dalam undang-undang tersebut adalah:

a. Mendukung bagi dilaksnakannya kegiatan koordinasi bagi pelaku pembangunan di Indonesia;

b. Merupakan jaminan dalam terwujudnya integrasi, sinkronisasi lintas sektor, antar daerah, serta antara pemerintah yang ada di pusat dengan pemerintah daerah;

c. Memberikan jaminan terkait keterikatan dan konsistensi dalam kegiatan perencanaan, penganggaran, implementasi dan pengawasan;

d. Optimalisasi dalam meningkatkan partisipasi masyarakat dalam pembangunan

e. Memberikan jaminan dalam penggunaan sumberdaya secara efektif, efisien, berkeadilan serta berkelanjutan.

Tjokroamidjodjo

(1995:57) mengemukakan bahwa seringkali terdapat pemahaman yang keliru terkait kegiatan 
perencanaan yang beranggapan bahwa kegiatan perencanaan terbatas pada penyusunan rencana saja, padahal perencanaan merupakan kegiatan yang berlangsung terus menerus dan menyeluruh yang terdiri atas penyusunan rencana, penyusunan program dan kegiatan, pelaksanaan rencana, serta pengawasan dan evaluasi rencana.

Sistem Perencanaan pembangunan Nasional juga menjelaskan tentang empat tahapan yang harus dilalui dalam pelaksanaan perencanaan pembangunan di Indonesia, empat tahapan tersebut terdiri atas:

a. Penyusunan Rencana

Tahap penyusunan rencana dilaksanakan dengan tujuan untuk menghasilkan sebuah rencana menyeluruh dari beragam aspek yang kemudian siap untuk ditetapkan menjadi sebuah dokumen perencanaan resmi.

b. Penetapan Rencana

Tahap penetapan rencana dilakukan untuk menetapkan payung hukum yang menjadi landasan bagi rencana yang telah dirumuskan pada tahapan sebelumnya.

c. Pengendalian Pelaksanaan Rencana

Tujuan dari keberadaan tahap ini adalah untuk memberikan jaminan atas terwujudnya tujuan serta sasaran pembangunan yang telah ditetapkan dalam rencana melalui penyesuaian-penyesuaian atas rencana yag dilakukan oleh pimpinan Menteri, pimpinan lembaga atau pimpinan organisasi perangkat daerah.

d. Evaluasi Pelaksanaan Rencana

Evaluasi merupakan kegiatan pengumpulan dan analisis data serta informasi yang digunakan untuk menilai capaian atas kinerja pembangunan yang dilaksnaakan pada periode waktu tertentu. Tahap evaluasi dilakukan mendasarkan pada indicator kinerja serta sasaran yang telah ditetapkan yaitu terkait dengan masukan, keluaran, hasil manfaat dan dampak.

Perencanaan digambarkan oleh Conyers dan Hills (1990:15) dalam tiga aktivitas yang salin terkait satu dengan yang lainnya, satu aktivitas diikuti oleh aktivitas lainnya. Aktivitas tersebut diawali dengan pengambilan kebijakan, lalu dikembangkan lewat proses perencanaan dan kemudian diimplementasikan. Perencanaan digambarkan oleh Conyers dan Hills seakan-akan sebagai sebuah fase peralihan antar kebijakan yang telah diambil dan implementasi dari kebijakan. Program-program aksi merupakan terjemahan dari dari kebijakan yang telah dirumuskan sebelumnya. Conyers and Hills (1990) menggambarkan proses perencanaan sebagai sebuah siklus tertutup, di mana setiap tahap terdapat sebuah tujuan tertentu, maka dari itu, diperlukan suatu pemahaman yang baik terkait tahapan yang terdapat pada siklus perencanaan tersebut. Tahapan-tahapan tersebut digambarkan oleh Conyers and Hills dalam gambar berikut:

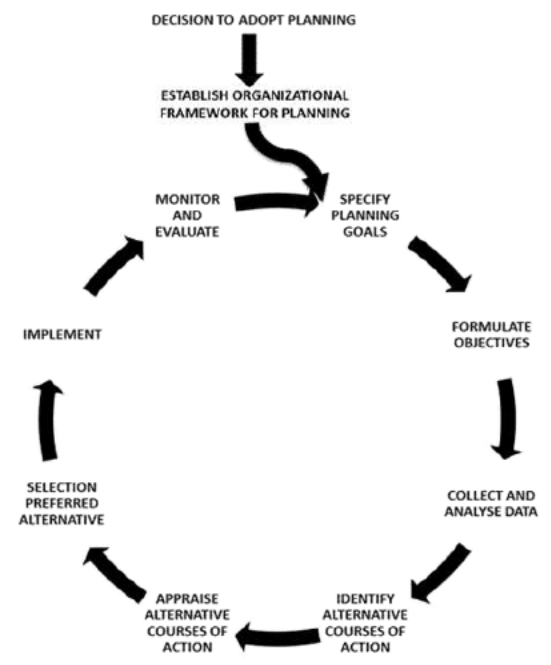

Gambar 2. Proses Perencanaan

Sumber : Conyers dan Hills (1990, h.74)

Nordiawan (2006) mengungkapkan bahwa terdapat persamaan antara organisasi sector publik dan swasta, yakni terkait keterbatasan dalam sumber daya. Keduanya menurut Nordiawan (2006) memiliki proses manajemen keuangan dan akuntansi manajemen yang relatif samameskipun berbeda dalam teknis pelaksanaan serta dalam hal indicator kinerja pada masing-masing sektor tersebut Pada sektor publik, sebagaimana diungkapkan Nordiawan (2006), agar kegiatan perencanan dan pengendaliannya dapat dilakukan dengan baik maka perlu ditopang oleh informasi lengkap dalam mendukung perencanaan dan pengendalian yang dilakukan. Untuk mendapatkan informasi tersebut, maka dilakukan melalui proses akutansi manajemen. Akutansi manajemen sebagaimana disampaikan Nordiawan (2006) mengutip pendapat dari The Chartered Institute mencakup aktivitas inti yang terdiri dari adanya partisipasi pada proses perencanaan di tingkatan strategis dan operasional, pembuatan panduan untuk keputusan manajemen dan memberikan 
kontribusi dalam kegiatan pengawasan dan pengendalian kinerja

Tjokroamidjojo (1995) menyampaikan bahwa untuk menunjang keberhasilan perencanaan dan pelaksanaan pembangunan diperlukan keterlibatan aktif dari masyarakat. Keterlibatan aktif atau partisipasi tersebut dapat berarti keterlibatan dalam proses penentuan arah, perumusan strategi serta kebijakan dalam pembangunan yang akan dilakukan oleh pemerintah pusat dan daerah. Ningsih (2012) mengungkapkan bahwa idealnya perencanaan dikatakan partisipatif apabila prosesnya mengikutsertakan semua pihak dalam rangka memecahkan masalah yang dihadapi yang bertujuan untuk mencapai kondisi yang diinginkan, tetapi dalam proses perencanaan ini hanya melibatkan bagian dari unsur masyarakat diantaranya eksekutif dan legislatif. Pada organisasi sektor publik, partisipasi hendaknya dilakukan oleh semua unsur dalam organisasi tersebut.

Anggaran, sebagaimana diungkapkan oleh Mardiasmo (2009:62) menggambarkan tentang estimasi kinerja yang akan dilaksanakan dalam kurun waktu tertentu serta dirupakan dalam nilai uang. Pada sektor publik, anggaran dapat berupa rincian rencana kegiatan serta merupakan representasi dari penerimaan dan belanja atau pengeluaran pada kurun waktu tertentu. Anggaran pada sektor publik juga harus memuat tentang biaya yang diperlukan oleh sebuah organisasi publik dalam melaksanakan rencana kegiatan yang telah disusun serta metode dalam memperoleh pendapatan untuk membiayai rencana tersebut.

Freeman dalam Nordiawan (2009:48) memberikan definisi anggaran sebagai proses pada sebuah organisasi sektor publik dalam pengalokasian sumber daya yang dipunyai oleh organisasi tersebut dalam memnuhi kebutuhankebutuhan organisasi yang tidak terbatas. Pengertian tersebut menggaris bawahi tentang pentingnya peran anggaran dalam mengelola kekayaan di organisasi publik. Pada suatu organisasi sektor publik, adanya keterbatasan kepemilikan sumber daya seringkali menjadi penghambat upaya dalam pemberian pelayanan terbaik bagi masyarakat.

Pada sebuah organisasi publik, dalam penyusunan anggaran terdapat dua pendekatan yang lazim dipraktekkan, yaitu pendekatan top down dan bottom-up. Pendekatan bottom-up memungkinkan adanya partisipasi dari pegawai atau pelaksana anggaran untuk berperan pada proses pencapaian tujuan organisasi. Partisipasi penyusunan anggaran merupakan pendekatan manajerial yang umumnya dinilai dapat meningkatkan efektifitas organisasional melalui peningkatan kinerja setiap anggota organisasi secara individual atau kinerja manajerial (Sukardi, 2002).

Dalam proses penyusunan anggaran, menurut Sukardi (2002) dibutuhkan partisipasi aktif dari manajemen level puncak dalam menelaah dan pengesahan anggaran, sehingga pengesahan anggaran tidak hanya sekedar stempel saja. Tanpa partisipasi aktif akan dapat memberikan peluang bagi para pelaksana anggaran untuk mempermainkan anggaran atau bahkan memberikan informasi kinerja yang tidak sesuai dengan kondisi organisasi yang sesungguhnya atau biasa dikenal dengan pemberian informasi yang tidak simetris. Hal tersebut biasa terjadi karena adanya ketidaksamaan dalam penguasaan informasi oleh manajer atau pihak eksekutif dibanding dengan pihak-pihak lain seperti pemegang saham atau legislatif dalam tataran sebuah pemerintahan. Ujiyantho (2004) mengungkapkan bahwa asimetri informasi yang terjadi diantar pihak manajemen selaku agent dengan pemilik atau principal membuka peluang yang lebar bagi manajer untuk mengambil keuntungan pribadi dari kondisi yang terjadi.

Teori tentang hubungan kedua pihak tersebut populer dikenal sebagai teori keagenan. Menurut Lane (2003) dalam Halim (2010) teori tentang keagenan juga disinyalir terjadi pada organisasi sektor publik. Dalam prakteknya, Lane menyatakan bahwa negara demokrasi modern didasarkan pada serangkaian hubungan prinsipal-agen. Jensen dan Meckling (1976) dalam Halim (2010) menyatakan bahwa hubungan keagenan adalah sebuah kontrak antara manajer (agent) dengan pemegang saham (principal). Hubugan kegenan tersebut terkadang menimbulkan masalah antara manajer dan pemegang saham.

Menurut Wildavsky dan Caiden (2004) dalam Pratiwi (2012) proses penganggaran adalah sebuah kondisi dimana bercampurnya beragam kepentingan serta kelompok yang berupaya untuk mewujudkan kepentingan mereka masing-masing dan menghasikan keputusan yang beragam. Menurut Rubin (1992) dalam Pratiwi (2012) penganggaran pada organisasi sektor publik merupakan cerminan dari beragam aktor yang terlibat 
dalam penganggaran yang masing-masing memilki agenda masing-masing terhadap anggaran.

Tahapan penyusunan anggaran yang dilakukan sebuah organisasi sektor publik menurut Nordiawan (2009) meliputi empat langkah yaitu ;

a. Penetapan Visi, Misi dan Strategi

Visi dan Misi merupakan sebuah pandangan jauh kedepan yang akan dituju oleh sebuah organisasi beserta cara dalam mewujudkannnya.

b. Pembuatan Tujuan

Tujuan merupakan sebuah titik yang akan dituju oleh sebuah organisasi dalam satuan waktu tertentu atau biasa dikenal dengan tujuan operasional. Tujuan operasional merupakan penjabaran dari visi misi organisasi sehingga akan menjadi panduan dalam mengalokasikan segenap sumber daya yang tersedia

c. Penetapan Aktivitas

Tahapan selanjutnya adalah menetapkan aktivitas yang akan ditempuh sesuai dengan tujuan dan strategi yang telah ditentukan

d. Evaluasi dan Pengambilan Keputusan Langkah selanjutnya setelah pengajuan anggaran disiapkan adalah proses evaluasi dan pengambilan keputusan.

Kemenkeu (2014) menjabarkan beberapa prasyarat agar penganggaran sebuah organisasi sektor publik dapat dikatakan efektif, yaitu adanya penyelarasan proses penganggaran dengan perencanaan serta tata kelola organisasi, penerapan perencanaan dan penganggaran secara komprehensif melalui koordinasi serta quality assurance secara efektif serta adanya monitoring dan evaluasi dalam penerapan anggaran berbasis kinerja.

Integrasi antara penganggaran dengan perencanaan sangat diperlukan oleh sebuah organisasi sector publik dalam mencapai tujuannya serta menetapkan prioritas tertentu dalam pengalokasian sumber daya yang dimilikinya. Ketika sebuah organisasi sektor publik menyusun perencanaan strategis, hendaknya didukung pula dengan perencanaan aktivitas dan sumber daya, baik berupa manusia maupun sumber daya yang lain. Hal tersebut perlu dilakukan untuk memastikan ketersediaan sumber daya dalam melaksanakan strategi guna mencapai tujuan dan sasaran.Dengan adanya integrasi tersebut, penganggaran tahun berjalan dan tahun-tahun berikutnya akan sejalan dengan tujuan dan prioritas organisasi. Selain itu, integrasi akan memberikan pemahaman yang lebih baik antar pimpinan organisasi terkait kegiatan dan anggaran yang mendukung tugas dan fungsi organisasi.(Better Practice Guide Penganggaran Berbasis Kinerja Kemenkeu , 2014).

Anggaran berbasis kinerja menurut Mardiasmo (2009) merupakan sebuah sistem penganggaran yang menitikberatkan pada usaha-usaha dalam mencapai hasil atau kinerja atau output atas biaya atau input yang telah dialokasikan melalui mekanisme perencanaan. Anggaran berbasis kinerja sangat menjunjung tinggi pencapaian hasil kinerja secara efektif, efisien, ekonomis dan adanya pengawasan dalam kinerja output, alokasi berdasarkan prioritas tujuan, serta menuntut dikedepankannya rasionalitas dalam proses pengambilan keputusan.

Tiga komponen dasar yang disyaratkan oleh pemerintah dalam penerapan penganggaran berbasis kinerja sebagaimana tercantum dalam PP 21 Tahun 2004 Tentang Penyusunan Rencana Kerja Anggaran bagi Kementerian Negara atau Lembaga yaitu:

1. Indikator Kinerja. Indikator kinerja dapat berperan dalam penilaian atas keberhasilan program atau kegiatan yang telah dilaksanakan. Indikator kinerja dapat berupa Indikator Kinerja Utama pada tataran program, Indikator Kinerja Kegiatan pada tataran kegiatan serta indikator keluaran pada level sub kegiatan.

2. Standar Biaya. Standar biaya merupakan estimasi biaya dan acuan tertinggi biaya yang diperlukan dalam melaksanakan sebuah aktivitas dalam pelaksanaan sebuah kegiatan, terdiri dari standar biaya masukan yang dikeluarkan oleh Menteri Keuangan serta standar biaya khusus yang disusun oleh Kementerian atau lembaga. Standar biaya dapat berfungsi dalam proses perencanaan serta penyusunan anggaran.

3. Evaluasi Kinerja. Evaluasi kinerja dapat berperan dalam menilai dan mengungkap permasalahan dalam pelaksanaan sebuah kebijakan serta memberikan masukan terkait efektifitas dan efisiensi dari program atau kegiatan yang dilaksanakan.

Mardiasmo (2009) menjabarkan sistem pengukuran kinerja sektor publik sebagai sebuah sistem yang bertujuan untuk melakukan 
penilaian atas capaian sebuah strategi baik dalam ukuran finansial maupun non finansial. Pengukuran tersebut sebagaimana disampaikan Mardiasmo (2009) mempunyai maksud untuk membantu memperbaiki kinerja pemerintah, kemampuan dalam mengalokasikan sumber daya yang tersedia, serta sebagai pertanggungjawaban publik dan perbaikan komunikasi kelembagaan. Untuk melakukan pengukuran kinerja, variabel kunci yang melekat dijabarkan menjadi indikator kinerja sebuah organisasi sector publik. Mekanisme dalam menentukan indikator kinerja dijelaskan oleh Mardiasmo (2009) hendaknya mempertimbangkan:

1. Sistem perencanaan serta pengendalian yang diterapkan

2. Spesifikasi teknis dan pengendalian

3. Kompetensi yang bersifat teknis serta profesionalisme

4. Mekanisme terkait Ekonomi dan Pasar

5. Mekanisme SDM

Monitoring dan pengkajian ulang terhadap indikator kinerja yang ditetapkan sebuah organisasi sektor publik harus terus menerus dilakukan sebagai bagian dari upaya perbaikan dan peningkatan kualitas pelayanan kepada masyarakat. Mardiasmo (2009:128) menyebutkan bahwa dalam sebuah organisasi sektor publik, indikator kinerja dapat mempunyai beberapa peran,yaitu:

1. Untuk membantu memperjelas tujuan organisasi

2. Untuk mengevaluasi target akhir yang dihasilkan

3. Masukan dalam memformulasi insentif bagi jajaran manajer

4. Membuka kemungkinan bagi pengguna jasa layanan publik untuk menentukan pilihan

5. Untuk menunjukkan standar kinerja

6. Untuk menunjukkan efektifitas

7. Membantu dalam penentuan aktivitas dengan efektifitas penggunaan biaya terendah dalam menuju target sasaran

8. Menuntun dalam memberikan masukan untuk perbaikan dalam melakukan penghematan biaya

Mardiasmo (2009) mengungkapkan bahwa digunakannya indikator kinerja sangat diperlukan dalam mendeteksi dan mengukur efektifitas dan efisiensi dari kegiatan yang telah dilaksanakan. Indikator kinerja yang terdapat pada organisasi sector public berbeda beda tergantung pada kegiatan serta layanan kepada masyarakat yang dilaksanakan oleh organisasi tersebut. Value for money menurut Mardiasmo (2009) adalah bagian inti dilakukannya pengukuran terhadap kinerja pada organisasi sektor publik.Indikator kinerja, pengembangannya hendaknya memperhatikan faktor ekonomi, efisiensi dan efektivitas program dan kegiatan. Aspek ekonomis, efisien dan efektif dapat memiliki arti hasil yang diperoleh merupakan nilai terbesar berbanding dengan jumlah input yang telah dikeluarkan serta mampu melebihi standar yang telah ditetapkan serta dampak yang besar di masyarakat dibanding periode sebelum dilakukan aktivitas serta melampaui capaian target yang telah ditetapkan. Mardiasmo (2009:132) berkesimpulan bahwa ketiga unsur dalam value for money yaitu ekonomi, efisiensi dan efektivitas sangat terkait satu dengan yang lainnya.

\section{METODE PENELITIAN}

Metode yang dipergunakan oleh peneliti dalam melaksanakan penelitian ini adalah dengan pendekatan kualitatif dengan metode deskriptif. Data yang digunakan oleh peneliti berupa data primer dan sekunder. Teknik pengumpulan data dilakukan melalui observasi, wawancara, dan dokumentasi. Dokumendokumen yang dikaji dalam penelitian ini berupa Renstra Polbangtan Malang, Rencana Kerja, Rencana Kerja Anggaran Kementerian/Lembaga (RKAKL) Polbangtan Malang, LAKIP, Daftar Isian Pelaksanaan Anggaran (DIPA) serta dokumen-dokumen lain yang berkaitan dengan permasalahan penelitian. Analisis data yang diginakan dalam penelitian ini menggunakan model Miles and Hubberman yang meliputi 4 aktivitas utama, yaitu Data Collection, Data Condensation, Data Display, serta Conclusion Drawing atau Verifications

\section{HASIL DAN PEMBAHASAN}

Sumber anggaran yang membiayai kegiatan pendidikan di Polbangtan Malang berasal dari anggaran Pemerintah (Kementerian Pertanian) yang bersumber dari APBN. Kebijakan operasional penggunaan anggaran tersebut sepenuhnya dilaksanakan oleh Polbangtan Malang sebagai penyelenggara pendidikan, dan sekaligus sebagai unit pelaksana teknis. Pelaksanaan Angaran Pendapatan dan Belanja Negara pada suatu tahun anggaran, menurut Undang-Undang Nomor 17 Tahun 2003 tentang Keuangan Negara dan Undang-Undang Nomor 1 Tahun 
2004 tentang Perebendaharaan Negara dimulai dengan tahapan penyusunan dan pengesahan dokumen pelaksanaan anggaran. Pada pemerintah pusat, dokumen pelaksanaan anggaran tersebut dikenal sebagai DIPA (Daftar Isian Pelaksanan Anggaran). DIPA pada Kementerian atau Lembaga disusun oleh pengguna anggaran mengacu pada rencana kerja dan anggaran yang terdapat pada masingmasing Kementerian atau Lembaga setelah terlebih dahulu mendapatkan persetujuan dari Dewan Perwakilan Rakyat (DPR RI). DIPA sebuah Kementerian atau Lembaga ditetapkan dalam sebuah Peraturan Presiden yang memuat detail rincian APBN yang telah terlebih dahulu ditelaah dan disetujui oleh Menteri Keuangan selaku Bendahara Umum Negara. Pada sebuah Kementerian atau Lembaga, Rencana Kerja dan Anggaran Kementerian Lembaga (RKAKL) berfungsi sebagai rujukan dalam penyusunan DIPA yang merupakan dasar dalam melaksanakan program, kegiatan dan anggaran pada suatu tahun anggaran yang ditetapkan pada tahun sebelumnya melalui payung hukum Keputusan Presiden.

Dalam siklus penganggaran pada pemerintah pusat dimana Polbangtan Malang menjadi bagian didalamnya, penyusunan RKA$\mathrm{K} / \mathrm{L}$ merupakan sebuah tahapan penting yang dilalui oleh sebuah satuan kerja pada pemerintah pusat karena merupakan sebah titik dimana keputusan terkait pelaksanaan suatu kegiatan yang akan dilaksanakan pada suatu tahun anggaran beserta alokasi pendanaan dilakukan pada tahap ini. RKAKL pada suatu tahun anggaran merupakan sebuah penjabaran dari dokumen perencanaan yang terdapat pada Kementerian atau Lembaga yang diturunkan kebawah sampai level satuan kerja atau Unit Pelaksana Teknis pada Kementerian atau Lembaga Tersebut. Penysunan RKAKL merupakan tanggungjawab dari suatu Kementerian atau Lembaga sebagaimana tertuang dalam Peraturan Pemerintah Nomor 90 tahun 2010 tentang Rencana Kerja dan Anggaran Kementerian Negara/Lembaga. Kementerian atau Lembaga juga berperan sebagai Chief Operational Officer (COO) dalam pengelolaan keuangan negara.

Pagu anggaran Polbangtan Malang dalam penyelenggaraan pendidikan DIV terus mengalami kenaikan pada tahun 2016-2019. Pada periode tersebut, kenaikan pagu anggaran terus terjadi pada jenis belanja barang meskipun sempat mengalami penurunan pada tahun 2018 .
Pada jenis belanja modal, dari tahun ke tahun juga mengalami kenaikan mengingat besarnya kebutuhan untuk rehab bangunan fisik kelas serta laboratorium yang di beberapa titik sudah dalam kondisi rusak berat. Kenaikan pagu anggaran tersebut, selain dialokasikan untuk kegiatan pembelajaran, rehab, serta pemenuhan sarana prasarana pembelajaran juga disebabkan oleh adanya penugasan-penugasan khusus yang diberikan oleh eselon I dalam mendukung tercapainya swasembada dan swasembada pangan berkelanjutan di Indonesia yang merupakan sasaran utama dari Kementerian Pertanian dalam Nawacita pemerintahan Presiden Joko Widodo. Penyelenggaraan pendidikan pertanian di Indonesia, sebagaimana tercantum dalam dokumen Renstra BPPSDMP 2014-2019, saat ini menghadapi beberapa persoalan utama yang kemudian juga menjadi tugas Polbangtan Malang untuk berkontribusi dalam mengatasi permasalahan tersebut, yaitu:

1. Menurunnya minat generasi muda untuk melanjutkan pendidikan ke SMK PP maupun STPP;

2. Menurunnya minat generasi muda untuk bekerja di sektor pertanian;

3. Belum memadainya kondisi sarana prasarana penunjang pendidikan;

4. Rendahnya kompetensi dan profesionalisme SDM pendidikan pertanian.

Upaya dalam mewujudkan Visi Politeknik Pembangunan Pertanian Malang yaitu Menjadi Perguruan Tinggi yang Berdaya Saing dan Berwawasan Global dalam Mencetak Sumber daya Manusia Profesional di Bidang Rumpun Ilmu Hayat Pertanian, menjadikan Renstra Polbangtan Malang 2015-2019 menjadi pedoman utama dalam mencapai tujuan organisasi dalam jangka panjang. Rencana strategis 2015 -2019 ini menjadi landasan penyusunan Rencana Kegiatan dan Anggaran Tahunan Polbangtan Malang. Operasionalisasi rencana strategis ini akan dilengkapi oleh dokumen rencana kerja tahunan yang dilengkapi dengan penetapan target dan indikator kinerja serta unit kerja yang menjadi penanggung jawab dalam implementasi. Berdasarkan beberapa isu strategis dalam penyelenggaran pendidikan pertanian tersebut, maka dilakukanlah berbagai upaya dalam memperbaiki dan memajukan pendidikan pertanian yang salah satunya dilakukan melalui penambahan alokasi anggaran pada Polbangtan untuk memperbaiki performa bangunan, sarana 
prasarana penunjang serta kualitas pembelajaran.

Proses perencanaan yang dilakukan oleh Polbangtan Malang mengacu pada tahapan yang terdapat dalam Undang-Undang Nomor 25 Tahun 20004 Tentang Sistem Perencanaan Pembangunan Nasional. Undang-Undang tersebut memuat 4 tahapan dalam proses perencanaan, yaitu penyusunan rencana, penetapan rencana, pengendalian pelaksanaan rencana, dan evaluasi pelaksanaan rencana. Kegiatan penyusunan rencana yang dilakukan di Polbangtan Malang diawali dengan melakukan evaluasi atas pelaksanaan kegiatan di tahun sebelumnya melalui sebuah forum rapat kerja akhir tahun yang diikuti oleh beragam unsur yang terdapat di Polbangtan Malang. Dalam forum tahunan yang dilaksanakan pada bulan Desember tersebut, dipaparkan capaian kinerja organisasi ditahun sebelumnya, hambatan dalam pelaksanaan kegiatan, serta potensi pengembangan atas kegiatan yang telah dilaksanakan. Output yang dihasilkan melalui forum rapat evaluasi berupa informasi terkait evaluasi atas tingkat keluaran (output); capaian Hasil (outcome); konsistensi antara perencanaan dan implementasi; dan realisasi penyerapan anggaran yang kemudian akan menjadi masukan bagi perumusan perencanaan untuk tahun depan. Pada tataran teknis di Internal Polbangtan Malang, bahan penyusunan rencana kerja dan anggaran disiapkan atau dilakukan oleh Staff Subbagian keuangan yang menangani perencanaan dikarenakan belum tersedianya bagian dalam struktur organisasi yang secara khusus menangani perencanaan. Bahan-bahan penyusunan rencana tersebut meliputi usulan rencana kegiatan dari jurusan, program studi, unit, bagian, unit penunjang, instalasi dan laboratorium yang ada di Polbangtan Malang dengan tetap berpedoman pada Renstra Polbangtan Malang serta arahan dari direktur terkait program pengembangan serta sasaran dalam pembangunan pendidikan pertanian. Data yang sudah terkumpul diolah dan disusun menjadi logframe rencana kerja dan anggaran. Logframe tersebut kemudian disajikan kepada direktur untuk kemudian dibawa ke forum pimpinan serta dilakukan harmonisasi dengan target keluaran, arah kebijakan dan strategi yang telah ditetapkan oleh unit eselon I BPPSDM Pertanian.

Logframe rencana kerja dan anggaran yang sudah dibicarakan dan disepakati dalam forum pimpinan tersebut selanjutnya di upload ke dalam aplikasi E-Proposal Kementerian Pertanian serta Aplikasi Sistem Informasi Perencanaan dan Anggaran (Sicanda) lingkup BPPSDMP. Aplikasi E-Proposal merupakan aplikasi perencanaan lingkup Kementerian Pertanian berbasis internet yang bertujuan untuk menampung usulan kegiatan dari level UPT maupun dari Pemerintah daerah dalam pembangunan pertanian atau lebih dikenal dengan pendekatan bottom up planning. Adapun Sicanda adalah aplikasi online yang mewadahi pengajuan usulan kegiatan dan anggaran lingkup BPPSDM Pertanian. Pengajuan usulan kegiatan dan anggaran yang diajukan Polbangtan melalui apliaksi Eproposal dan Sicanda dilakukan pada waktu yang hampir bersamaan dengan menyertakan kerangka acuan kerja (KAK), rencana anggaran biaya (RAB), dan rencana operasional kegiatan (ROK) serta beragam data dukung lainnya. Pengajuan usulan kegiatan dan anggaran ke Eselon I BPPSDM Pertanian serta Biro Perencanaan Kementerian Pertanian melalui mekanisme E-Proposal dan Sicanda menyertakan kelengkapan dokumen berupa Kerangka Acuan Kerja atau Term Of Reference (TOR), Rencana Anggaran Belanja (RAB) serta Rencana Operasional kegiatan (ROK). Kerangka Acuan Kerja dibuat oleh masingmasing pelaksana kegiatan dengan pertimbangan bahwa merekalah yang mengerti kondisi riil di lapangan serta pelaksana langsung kegiatan.

Polbangtan Malang sebagai satuan kerja unit eselon II menyusun RKA-K/L pada tingkat unit operasional yang kemudian disampaikan kepada Bagian Perencanaan unit eselon I dengan terlebih dahulu dilakukan review oleh Pusat Pendikan Pertanian sebagai koordinator penyelenggaraan pendidikan pertanian, untuk selanjutnya dihimpun dan diharmonisasi sebagai dokumen RKAK/L BPPSDMP Pertanian. BPPSDM Pertanian sebagai unit eselon I menyampaikan dokumen RKAKL tersebut kepada Biro Perencanaan Sekretariat Jenderal (Setjen) yang selanjutnya menghimpun dan mengharmonisasi sebagai RKA-K/L tingkat K/L. Pada tahap berikutnya, dokumen RKAKL disampaikan ke Inspektorat Jenderal Kementerian Pertanian selaku Aparat Pengawasan Internal Pemerintah (APIP) untuk dilakukan review RKAK/L unit eselon I. Biro Perencanaan Setjen pada tingkat $\mathrm{K} / \mathrm{L}$ melakukan penelitian RKA-K/L dengan cara 
memverifikasi dan memeriksa kebenaran dan kesesuaian dokumen dengan aturan dan batasan yang telah ditentukan. Verifikasi tersebut terkait dengan beberapa aspek, yaitu:

1. Kesesuaian dan akurasi dalam pencantuman sasaran kinerja yang terkait dengan volume keluaran, dan Indikator Kinerja kegiatan dalam RKAK/L dengan sasaran kinerja yang tertera dalam Rencana Kerja Kementerian atau Lembaga serta Rencana Kerja Pemerintah (RKP);

2. Kesesuaian total pagu dalam RKA-K/L dengan pagu anggaran K/L;

3. Kebenaran dan kesesuaian dalam mencantumkan sumber pendanaan yang tertera dalam RKAK/L dengan sumber pendanaan yang telah ditetapkan pada pagu anggaran suatu Kementerian atau Lembaga;

4. Kepatuhan dalam pencantuman tematik APBN pada tingkat keluaran (output);

5. Kebenaran serta kelengkapan dokumendokumen pendukung RKAK/L yang terdiri dari Rencana Kerja Anggaran Satuan Kerja atau UPT, Kerangka Acuan Kerja (KAK) dan $\mathrm{RAB}$ serta dokumen terkait lainnya.

Berdasarkan program yang akan dilaksanakan oleh Polbangtan Malang, usulan DIPA Polbangtan Malang selanjutnya dihimpun dalam DIPA induk BPPSDM Pertanian yang merupakan unit eselon I dari Polbangtan Malang sesuai dengan mekanisme yang tertera dalam Peraturan Menteri Keuangan (PMK) 94 Tahun 2017 tentang Petunjuk Penyusunan dan Penelaahan Rencana Kerja dan Anggaran Kementerian Negara/Lembaga dan Pengesahan Daftar Isian Pelaksanaan Anggaran. Dalam PMK tersebut dijelaskan bahwa dasar dalam penyusunan DIPA induk bersumber dari Rencana Kerja Anggaran pada unit eselon I yang telah disetujui oleh DPR RI, sesuai dalam alokasi anggaran Kementerian, melewati tahap penelaahan oleh Direktorat Jenderal Anggaran dan telah ditetapkan dalam Perpres rincian APBN. Pengesahan DIPA menurut PMK Nomor 94 Tahun 2017 pada intinya merupakan penetapan dari Menteri Keuangan serta merupakan jaminan terkait ketersediaan pendanaan dari DIPA tersebut dalam APBN tahun berjalan serta menjadi dasar dalam pencairan dana oleh Kementerian Keuangan selaku bendahara umum negara melalui Kantor Pelayanan Perebendaharaan Negara (KPPN) di wilayah kerja masingmasing. Sesuai dengan Peraturan Menteri
Keuangan (PMK) Nomor 94 Tahun 2017, pengesahan DIPA ditandai dengan diterbitkannya Surat Pengesahan (SP) DIPA yang ditandatangani oleh Dirjen Anggaran Kementerian Keuangan yang berisi DIPA Induk unit eselon I Kementerian atau Lembaga dan SP DIPA petikan yang berisi rincian anggaran untuk satuan kerja vertical lingkup Kementerian. SP DIPA petikan bagi satuan kerja dapat dicetak dari aplikasi RKAKL oleh masing-masing satker yang terdapat kode pengaman berupa digital stamp yang berfungsi sebagai penanda keaslian menggantikan keberadaan tanda tangan pejabat yang berwenang mengesahkan pada DJA Kemenkeu.

Pengendalian atau pengawasan pelaksanaan rencana yang dimaksudkan oleh UU 25 tahun 2004 dilakukan dengan tujuan untuk memastikan tercapaianya sasaran dan tujuan dalam pembangunan yang telah dituangkan dalam rencana yang dilakukan melalui kegiatan-kegiatan koreksi dan penyesuaian selama pelaksanaan rencana tersebut oleh pimpinan. Kegiatan pengendalian atas pelaksanaan rencana kegiatan pada Polbangtan Malang dipimpin dan dilakukan secara langsung oleh Direktur Polbangtan serta dibantu oleh tim Satlak SPI yang dibentuk oleh direktur Polbangtan Malang dan tercantum dalam SK struktur organisasi setiap tahunnya. Tim Satlak SPI Polbangtan Malang secara periodik atas perintah direktur, melakukan kegiatan pengendalian pada beragam kegiatan dengan terlebih dahulu dilakukan pemetaan atas kemungkinan risiko yang mungkin terjadi pada kegiatan yang sudah terpetakan.

Dalam prakteknya, untuk menunjang kegiatan pemantauan seringkali direktur memberikan penugasan khusus kepada wakil direktur atau Kepala Bagian untuk melakukan kegiatan pengawasan atas kemajuan atau capaian suatu kegiatan. Kegiatan pengendalian yang dilakukan pada Polbangtan malang masih menitikberatkan pada aspek keuangan atau anggaran, yaitu pada realisasi anggaran dan pelaksanan Rencana Operasional Kegiatan (ROK) serta Rencana Kinerja Tahunan yang telah disusun di awal tahun . Rencana Operasional Kegiatan (ROK) adalah sebuah dokumen rencana pelaksaan kegiatanyang didalamnya memuat capaian dan prosentase serapan anggaran. Hal tersebut dilakukan karena anggaran juga merupakan salah satu indikator dilaksanakannya suatu kegiatan meskipun belum dapat menggambarkan secara 
menyeluruh terkait proses yang dilakukan dalam melaksanakan kegiatan, kendala yang ditemui serta strategi-strategi dalam memecahkan permasalahan di lapangan yang mungkin saja dapat berimplikasi hukum bagi organisasi secara keseluruhan. Mekanisme pengendalian pada aspek anggaran atau keuangan dilakukan melalui pembuatan laporan bulanan oleh Pejabat Pembuat Komitmen kepada direktur selaku kuasa pengguna anggaran terkait serapan anggaran dan progress kemajuan proyek pengadaan barang atau jasa yang dilakukan oleh pihak ketiga berdasarkan masukan dari sub bag keuangan selaku pengadministrasi keuangan. Pelaksana kegiatan sendiri juga masih banyak yang beranggapan atau berpandangan bahwa ukuran keberhasilan pelaksanaan kegiatan mereka adalah terserapnya anggaran dan cenderung mengabaikan outcome, dan impact atas kegiatan yang dilaksanakannya tersebut. Metode yang dilakukan dalam pengendalian adalah melalui supervisi langsung kepada penanggung jawab serta pelaksana kegiatan oleh direktur dan unsur pimpinan.

Evaluasi menurut definisi PP 39 tahun 2016 Tentang Tata Cara Pengendalian dan Evaluasi Pelaksanaan Rencana Pembangunan merupakan sebuah rangkaian kegiatan menilai realisasi masukan (input), keluaran (output) dan hasil (outcome) terhadap rencana dan standar yang telah ditetapkan. Indikator dan sasaran kinerja yang tertera dalam rencana pembangunan menjadi dasar dilakukannya kegiatan evaluasi. Kegiatan evaluasi secara menyeluruh atas pelaksanaan rencana salah satunya dilakukan oleh Polbangtan Malang melalui sebuah forum rapat kerja akhir tahun yang diikuti oleh beragam unsur yang terdapat di Polbangtan Malang. Dalam forum tahunan yang dilaksanakan pada bulan Desember tersebut, dipaparkan capaian kinerja organisasi serta pengukuran atas capaian ditahun sebelumnya, hambatan dalam pelaksanaan kegiatan, serta potensi pengembangan atas kegiatan yang telah dilaksanakan. Selain evaluasi menyeluruh atas capaian kinerja organisasi secara keseluruhan, evaluasi kinerja individu jajaran dibawahnya juga dilakukan oleh direktur. Evaluasi kinerja tersebut dilakukan mengingat masing-masing pejabat struktural tersebut di awal telah menandatangani perjanjian kinerja sebagai yang berfungsi sebagai indikator kinerja kontribusi mereka dalam pencapaian output serta mewujudkan tujuan organisasi secara keseluruhan.

Evaluasi juga dilakukan pada Rencana Kinerja Tahunan (RKT) dan Rencana Operasional Kegiatan (ROK) guna mengidentifikasi kendala-kendala yang dihadapi dalam pelaksanaan kegiatan yang sudah direncanakan sebelumnya agar bisa menjadi masukan dalam proses perencanaan tahun berikutnya. Pada aspek keuangan, dilakukan evaluasi atas realisasi dan efisiensi penggunaan dana. Hasil dari pertemuan tersebut kemudian menjadi masukan dalam penyusunan LAKIN Polbangtan Malang. Komponen dalam LAKIN yang disusun oleh staff sub bagian keuangan memuat evaluasi terkait penerapan komponen manajemen kinerja yang meliputi Perencanaan kinerja, Pengukuran kinerja, Pelaporan kinerja,Evaluasi internal, dan Capaian kinerja. Terkait monitoring dan evaluasi atas kinerja keuangan dan pengelolaan anggaran di, Kementerian Keuangan juga mengeluarkan pedoman dalam menilai kinerja pelaksanaan anggaran melalui PMK 195/PMK.05/2018 tentang Monitoring dan Evaluasi Pelaksanaan Anggaran Belanja K/L . Komponen dalam evaluasi kinerja pelaksanaan anggaran tersebut terdiri dari 12 komponen, yaitu: Revisi DIPA; Deviasi Halaman III DIPA; Pengelolaan Uang Persediaan;Laporan Pertanggungjawaban Bendahara; Penyampaian Data Kontrak; Penyelesaian Tagihan; Penyerapan Anggaran; Retur Surat Perintah Pencairan Dana; Perencanaan Kas; Pengembalian atau Kesalahan Surat Perintah Membayar;Pagu Minus; dan Dispensasi SPM.

Secara umum, tahapan dalam proses perencanaan yang digariskan dalam UndangUndang Nomor 25 tahun 2004 tentang Sistem Perencanaan Pembangunan Nasional sudah dilaksanakan oleh Polbangtan Malang. Meskipun demikian, masih terdapat beberapa hal yang belum dilakukan secara optimal sehingga dalam pelaksanaan atau implementasi masih sering terjadi perubahan atas apa yang direncanakan sebelumnya. Hal tersebut terjadi karena pada tahap penyusunan rencana, pengajuan usulan rencana kegiatan yang diajukan oleh pelaksana masih terbatas pada kegiatan rutinitas serta proyeksi keinginan dan belum mengacu pada rencana strategis institusi yang telah digariskan. Selain itu, pengajuan usulan rencana belum didukung oleh data dukung yang valid serta studi pendahuluan atau kajian yang bersifat mendalam sehingga dalam 
pelaksanaanya masih diperlukan penyesuaianpenyesuaian atau bahkan tidak dapat dilaksanakan sama sekali. Hal tersebut bertentangan dengan pendapat Tjokroamidjodjo (1995) yang menyampaikan bahwa dalam penyusunan rencana hendaknya didahului oleh suatu tinjauan keadaan atau review yang bisa berupa tinjauan sebelum dimulai suatu rencana serta tinjauan tentang pelaksanaan rencana sebelumnya. Setelah tinjauan keadaan, perlu juga dilakukan perkiraan atas keadaan masa yang akan dilalui oleh rencana, pemilihan caracara pencapaian tujuan rencana, serta identifikasi kebijaksanaan atau kegiatan yang perlu dilakukan dalam rencana. Sejalan dengan pendapat Tjokroamidjodjo, Akhadi K (2013) dalam penelitiannnya juga menyampaikan bahwa penggunaan data dan informasi yang valid serta terbaru dalam penyusunan perencanaan sangatlah diperlukan, karena dapat menjadi dasar untuk menyusun alternatif strategi. Conyers and Hills (1990) juga menyertakan tahap penggumpulan dan analisis data dalam proses perencanaan, yaitu collect and analyse data. Menurut Conyers and Hills (1990) pada tahap ini dibutuhkan analisa situasi untuk menentukan sifat dan masalah perencanaan. Pengumpulan data dan analisa data merupakan bagian dari identifikasi masalah, membutuhkan sumber daya keuangan, tenaga kerja terlatih dan akses ke berbagai macam fasilitas.

Tahapan lain dalam proses perencanaan yang belum dilakukan dengan baik oleh Polbangtan Malang adalah pengendalian dalam pelaksanaan rencana. Sering berubah-ubahnya kegiatan yang dilaksanakan oleh Polbangtan Malang merupakan gambaran nyata kurang efektifnya metode pengendalian melalui supervisi langsung kepada penanggung jawab serta pelaksana kegiatan yang dilakukan oleh direktur dan unsur pimpinan. Pengendalian terhadap personel saja menurut Mulyadi (2001) tidaklah cukup, karena masih terdapat kemungkinan terjadi ketidakselarasan tujuan individu dengan tujuan organisasi dan ketidakmampuan individu untuk mencapai tujuan organisasi karena minimnya kompetensi yang dimiliki. Oleh karena itu, menurut Mulyadi (2001:649) diperlukan pengendalian tambahan yaitu terhadap keluaran, pengendalian terhadap tindakan tertentu dan penghindaran organisasi dari penyimpangan yang dilakukan individu. Menurut Mulyadi (2001:645) keberhasilan perwujudan rencana sangat ditentukan oleh pengendalian yang didesain dan diimplementasikan oleh manajemen. Kemampuan manajemen dalam mendesain berbagai tipe pengendalian yang cocok dengan situasi yang dihadapi akan menjadi penentu keberhasilan organisasi dalam mewujudkan tujuan yang telah ditetapkan dalam proses perencanaan. Penyebab diperlukannya pengendalian dan tipe pengendalian yang efektif digambarkan oleh Mulyadi (2001) sebagai berikut:

Tabel 2. Penyebab diperlukannya pengendalian dan Tipe Pengendalian

\begin{tabular}{|c|c|}
\hline $\begin{array}{c}\text { Penyebab } \\
\text { diperlukannya } \\
\text { Pengendalian }\end{array}$ & $\begin{array}{l}\text { Tipe Pengendalian yang } \\
\text { Efektif }\end{array}$ \\
\hline $\begin{array}{l}\text { Keterbatasan } \\
\text { Individu: } \\
\text { Kurangnya atau } \\
\text { ketiadaan kompetensi } \\
\text { Personel } \\
\text { Keterbatasan yang } \\
\text { bersifat manusiawi }\end{array}$ & $\begin{array}{l}\text { Pengendalian Utama: } \\
\text { Pengendalian terhadap } \\
\text { personel } \\
\text { Pengendalian } \\
\text { tambahan: } \\
\text { Pengendalian terhadap } \\
\text { keluaran } \\
\text { Pengendalian terhadap } \\
\text { tindakan tertentu } \\
\text { Pengendalian terhadap } \\
\text { personel } \\
\text { Penghindaran organisasi } \\
\text { dari masalah } \\
\text { pengendalian }\end{array}$ \\
\hline
\end{tabular}

Sumber: Mulyadi (2001:647)

Dalam pelaksanaan penganggaran berbasis kinerja, akuntabilitas pengelolaan anggaran dan pencapaian kinerja dapat diwujudkan melalui kegiatan evaluasi. Tahap evaluasi sebagai bagian dari proses perencanaan yang dilaksanakan Polbangtan Malang masih terbatas pada penggunaan dana dan persentase pelaksanaan kegiatan dan belum mencakup evaluasi secara menyeluruh terkait dampak pelaksanaan program. Praktek evaluasi tersebut belum sepenuhnya sesuai dengan yang telah digariskan dalam PP Nomor 90 Tahun 2010 yang menyebutkan beberapa indikator dalam melakukan pengukuran dan evaluasi kinerja atas pelaksanaan yang paling sedikit terdiri atas tingkat efisiensi penggunaan anggaran, realisasi anggaran, capaian keluaran (output), capaian hasil (outcome), dan konsistensi antara perencanaan dan implementasi. Instrumen evaluasi dalam PP 90 tahun 2010 tentang Penyusunan Rencana Kerja dan Anggaran Kementerian Negara/Lembaga tersebut 
meskipun sudah terakomodir dalam LAKIN Polbangtan Malang yang disusun setiap tahunnya, namun penyusunannya dilakukan sebatas memenuhi kewajiban administratif lembaga dalam hal pelaporan kinerja dan belum menjadi dasar dalam evaluasi proses perencanaan serta penganggaran. Artinya, mekanisme pengalokasian penganggaran belum menjadikan hasil evaluasi sebagai rujukan utama dan masih berprinsip follow structure dengan tetap memfasilitasi anggaran setiap unsur yang ada di Polbangtan Malang dan belum berbasis kinerja yang akan dicapai. Mulihartanti (2013) juga mengungkapkan fenomena serupa dengan yang terjadi pada Polbangtan Malang dalam penelitiannya di Kota Administrasi Jakarta Utara. Hasil dari penelitian tersebut mengungkapkan masih diterapkannya pendekatan tradisional dalam praktek penyusunan anggaran, terutama dalam perencanaan anggaran, serta belum adanya sistem pengukuran kinerja terhadap outcome yang dihasilkan. Afandi dan Tarigan (2016) dalam penelitiannya di Dinas Tenaga Kerja Kota Tanjungbalai juga mengungkapkan tentang proses perencanaan anggaran berbasis kinerja yang belum disusun dengan pendekatan kinerja, hal tersebut terlihat dari pengukuran capaian kinerja yang masih dilihat dari besaran penyerapan anggaran yang dikeluarkan. Dari penjelasan tersebut dapat disimpulkan bahwa dalam melaksanakan proses perencanaan diperlukan dukungan data valid dan terbaru, adanya metode pengendalian rencana yang efektif serta adanya evaluasi atas pelaksanaan rencana yang telah ditetapkan.

\section{E. KESIMPULAN DAN SARAN Kesimpulan}

Secara umum, tahapan dalam proses perencanaan yang diamanatkan oleh sistem perencanaan pembangunan nasional telah dilaksanakan oleh Polbangtan Malang. Meskipun demikian, masih ditemui beberapa tahapan yang pelaksanaannya belum optimal sehingga dalam pelaksanaan atau implementasi masih sering terjadi perubahan atas apa yang direncanakan sebelumnya. Pada tahap penyusunan rencana, pengajuan usulan rencana kegiatan belum berdasar atas target kinerja yang akan dicapai serta belum didukung oleh data dukung yang valid serta studi pendahuluan atau kajian yang bersifat mendalam. Kurang efektifnya kegiatan pengendalian melalui supervisi langsung yang dilakukan oleh unsur pimpinan kepada penanggung jawab serta pelaksana kegiatan perlu disikapi dengan merumusukan kembali metode pengendalian yang efektif diterapkan di Polbangtan Malang. Tahap evaluasi sebagai bagian dari proses perencanaan yang dilaksanakan Polbangtan Malang masih terbatas pada penggunaan dana dan persentase pelaksanaan kegiatan dan belum mencakup evaluasi secara menyeluruh terkait dampak pelaksanaan program. Mekanisme pengalokasian anggaran yang dilakukan Polbangtan Malang belum menjadikan hasil evaluasi kinerja sebagai rujukan utama dan belum berorientasi pada kinerja yang akan dicapai

\section{Saran}

Pada tahap penyusunan rencana, guna memastikan ketersediaan data dan informasi valid serta terbarukan sebagai input dalam penyusunan rencana, maka perlu dilakukan studi pendahuluan atau kajian terkait kegiatan yang hendak dilaksnakan. Studi pendahuluan atau kajian perlu dilakukan agar bisa dihasilkan dokumen perencanaan yang baik dan akurat serta mudah dalam implementasinya. Dalam pengimplementasian penganggaran berbasis kinerja, maka diperlukan acuan atau pedoman di internal Polbangtan Malang terkait penggunaan ketiga unsur yang merupakan ciri utama dari anggaran berbasis kinerja, yaitu adanya indikator kinerja, penggunaan standar biaya serta evaluasi kinerja. Dalam mewujudkan tujuan yang telah ditetapkan dalam proses perencanaan, maka diperlukan sebuah desain pengendalian yang cocok, baik terhadap personel, terhadap keluaran, serta pengendalian terhadap tindakan tertentu

\section{DAFTAR PUSTAKA}

Adiwirya, M. F., \& Sudana, I. P. (2015). Akuntabilitas, Transparansi, dan Anggaran Berbasis Kinerja Pada Satuan Kerja Perangkat Daerah Kota Denpasar. E-Jurnal Akuntansi, 611-628

Afandi, M. N., \& Tarigan, F. F. A. (2016). Analisis Perencanaan Anggaran Berbasis Kinerja Pada Dinas Tenaga Kerja Kota Tanjung Balai Provinsi Sumatera Utara. Jurnal Ilmu Administrasi: Media Pengembangan Ilmu dan Praktik Administrasi, 13(1), 93-110. 
Akhadi, K., Wijaya, A. F., \& Hardjanto, I. (2013). Perencanaan Pembangunan Kehutanan Daerah dalam Perspektif Good Governance. Jurnal Penelitian Kehutanan Wallacea, 2(1), 51-64.

Andi, A., \& Sumartono, H. I. DOI https://doi. org/10.18551/rjoas. 2018-01.02 Agricultural Development Planning Based On Local Resources In Depok City, Indonesia. Russian Jurnal Of Agricultural and Socio-Economic Science, 10.

Andriani, W., \& Hatta, E. (2012). Analisis Penerapan Anggaran Berbasis Kinerja Pada Pemerintah Pusat (Studi pada Politeknik Negeri Padang). Jurnal Akuntansi \& Manajemen, 7(1), 24-35.

Anton, M. G., Tinangon, J. J., \& Elim, I. (2016). Penerapan Anggaran Berbasis Kinerja Untuk Menunjang Akuntabilitas Publik Pada Badan Lingkungan Hidup Kota Manado. Jurnal EMBA: Jurnal Riset Ekonomi, Manajemen, Bisnis dan Akuntansi, 4(3).

Anugerahani, I. D., \& WAHJONO, S. I. (2013). Pengaruh Implementasi Anggaran Berbasis Kinerja terhadap Kinerja Pegawai (Studi pada Badan Pengelola Keuangan dan Aset Daerah (BPKAD) Kabupaten Kediri). Jurnal Ilmu Manajemen, Revitalisasi, 2(2), 147-162.

Conyers, Diana And Peter Hills. 1990. An Introduction to Development Planning in The Third World. John Wiley \& Sons Chichester. New York

Conyers, Diana, 1994, Perencanaan Sosial di Dunia Ketiga: Suatu Pengantar, Gadjah Mada University Press, Yogyakarta.

Direktorat Jenderal Anggaran. 2006.Reformasi Sistem Penganggaran, Konsep dan Implementasi 2005-2007.Jakarta

Fitri, S. M., Ludigdo, U., \& Djamhuri, A. (2013). Pengaruh Gaya Kepemimpinan, Komitmen, Organisasi, Kualitas Sumber Daya, Reward, Dan Punishment Terhadap Anggaran Berbasis Kinerja (Studi Empirik Pada Pemerintah
Kabupaten Lombok Barat). Jurnal Dinamika Akuntansi, 5(2).

Halim, A., \& Abdullah, S. (2010). Hubungan dan Masalah Keagenan di Pemerintah Daerah. Jurnal Akuntansi Pemerintah, 2(1), 53-64.

Indonesia, Kementerian Keuangan Republik. Better Practice Guide Penganggaran Berbasis Kinerja. 2014.

Kemenkeu (2009) Pedoman Penerapan Penganggaran Berbasis Kinerja: Jakarta

Moleong, Lexy J. 2010. Metodologi Penelitian Kualitatif. Bandung: PT. Remaja Rosdakarya

Mardiasmo. (2009). Akuntansi Sektor Publik. Yogyakarta: Andi

Miles, M. B., Huberman, A. M., \& Saldana, J. (2013). Qualitative data analysis. Sage

Mulihartanti, Mirna Tri (2013) Analisis Penerapan Penganggaran Berbasis Kinerja Pada Pemerintah Kota Administrasi Jakarta Utara (Studi Kasus Untuk Tahun Anggaran 2011)

Mulyadi, J. S. (2001). Sistem Perencanaan dan Pengendalian Manajemen. Jakarta: Salemba Empat.

Nainggolan, A. (2016). Penganggaran Berbasis Kinerja dan Upaya Mewujudkan Good Government Governance. Jurnal Ilmiah METHONOMI, 2(1).

Ningsih, Y. T. (2012). Perencanaan Pembangunan Berbasis Masyarakat Yang Partisipatif (Studi Tentang Penyusunan Rencana Pembangunan Jangka Menengah Daerah Provinsi Kepulauan Bangka Belitung) (Doctoral dissertation, Universitas Terbuka).

Pradana, B. A., Handayani, B. D., \& Murtini, H. (2014). Determinan Implementasi Anggaran Berbasis Kinerja Badan Layanan Umum (Pada Universitas Negeri Semarang). Accounting Analysis Journal, 3(1). 
Pratiwi, R. N. (2012). Politisasi Anggaran Sektor Publik. Interaktif: Jurnal IlmuIlmu Sosial, 1(2).

Purnamasari, P. (2018). Pengaruh Penerapan Anggaran Berbasi Kinerja terhadap Kinerja Keuangan (Penelitian Pada Dinas Bina Marga Provinsi Jawa Barat: Balai Pengelolaan Jalan Wilayah Pelayanan V). Jurnal Edukasi (Ekonomi, Pendidikan dan Akuntansi), 5(2).

Robinson, Marc and D. Last. 2009. A Basic Model of Performance-Based Budgeting. Technical Notes and Manuals. International Monetary Fund.Washington.

Sukardi, S. (2002). Hubungan Antara Partisipasi Penyusunan Anggaran Dengan Kinerja Manajerial Peran Motivasi Icerja Dan Kultur Organisasional Sebagai Variabel Moderating (Studi Empiris pada Badan Usaha Koperasi di Jawa Tengah.) (Doctoral dissertation, Program Pascasarjana Universitas Diponegoro).

STPP Malang (2014) Renstra Sekolah Tinggi Penyuluhan Pertanian Malang: Malang

Syuliswati, A., \& Asdani, A. (2017). Pengaruh Perencanaan, Pelaksanaan, Pelaporan dan Evaluasi Anggaran Berbasis Kinerja terhadap Akuntabilitas Kinerja pada Politeknik Negeri Malang. Jurnal Akuntansi Bisnis dan Manajemen, 24(1), 1-17.

Tjokroamidjojo, B. (1995). Perencanaan pembangunan. Jakarta: Gunung Agung.

Ujiyantho, M. A. (2004). Asimetri informasi dan manajemen laba: Suatu tinjauan dalam hubungan keagenan. Simposium Nasional Akuntansi.

Undang Undang Nomor 17 Tahun 2003 tentang Keuangan Negara

Undang Undang Nomor 1 Tahun 2004 tentang Perbendaharaan Negara
Undang Undang Nomor 25 Tahun 2004 tentang Sistem Perencanaan Pembangunan Nasional 